\title{
In-vitro comparative evaluation of quality control parameters between paracetamol and paracetamol/caffeine tablets available in Bangladesh
}

\author{
*Palash Karmakar, Md. Golam Kibria \\ Department of Pharmacy, Noakhali Science and Technology University, Sonapur, Noakhali-3814, Bangladesh
}

\begin{abstract}
Paracetamol is a widely used non-prescription analgesic and antipyretic medicine. The study was conducted to assess the comparative in-vitro quality control parameters through the evaluation of weight variation, hardness, friability, disintegration time and dissolution profile between the commercially available tablet brands of paraceta$\mathrm{mol}$ and paracetamol/caffeine combination in Bangladesh. Tablets of five top level manufacturers those have both of the formulations were evaluated in two groups. Both similarities and dissimilarities were found between the groups. All tablets either paracetamol (1.07 to $2.14 \%)$ or paracetamol/caffeine $(0.98$ to $2.09 \%)$ showed acceptable weight variation and friability (below 1\%). Formulations were somewhat different in their hardness, disintegration time and dissolution profile. All tablets of paracetamol/caffeine were found harder than paracetamol tablets of the same manufacturer. 1 out of 5 for paracetamol and 3 out of 5 for paracetamol/caffeine tablets exceeded the limit of tablet hardness or crushing strength. The disintegration time in $0.1 \mathrm{~N} \mathrm{HCl}$ of paracetamol tablet brands (24 seconds to 4 minutes 52 seconds) were less than the paracetamol/caffeine ( 6 minutes 33 seconds to 17 minutes 43 seconds) brands. On the other hand in phosphate buffer, $\mathrm{pH} 7.4$, paracetamol/caffeine tablets dissolved quickly and showed better release profile than tablets containing only paracetamol. It can be concluded that standard quality control parameters always should be maintained not only for paracetamol or its combination but also for all kinds of medicine for getting better drug products.
\end{abstract}

Key Words: Paracetamol, caffeine, comparative, quality control parameters, evaluation.

\section{INTRODUCTION}

Paracetamol or acetaminophen is a widely used over-the-counter analgesic and antipyretic drug (Fiebich et al., 2000). Generally it is used to treat headache, other minor aches and pains and also in cold and flu remedies. It could also be used in the management of more severe pain like pain in cancer in combination with other drugs (Kalakuntla et al., 2010). At present, beside paracetamol, a new paracetamol/caffeine formulation is designed to deliver faster dissolving and more quickly absorbed drug product (Liu et al., 2011). Along with paracetamol, the combination product is also available and well established medicine in Bangladesh due to patients' acceptability (Islam et al., 2012).

\footnotetext{
*Corresponding Author:

Palash Karmakar, Lecturer

Department of Pharmacy

Noakhali Science and Technology University

Sonapur, Noakhali-3814, Bangladesh

E-mail:pknstu@gmail.com

Contact No.: +8801717036968
}

Caffeine is a central nervous system stimulant, naturally produced in the leaves and seeds of many plants. It increases alertness, boosts up energy and elevates mood of most of the peoples (Islam et al., 2012). It is a common adjuvant for analgesic drugs such as paracetamol and acetylsalicylic acid (Smith, 1998; Sawynok and Yaksh, 1993; Lipton et al., 1998; Ward et al., 1991; Liu et al., 2011). Moreover, solubility of paracetamol is increased in the presence of caffeine (Okore and Osuji, 2001). Caffeine also accelerates the absorption of paracetamol and therefore provides enhanced and prolonged analgesic activity (Renner et al., 2007).

The clinical effectiveness exerted by tablet formulation depends on at least two factors such as, the drug must be present in the labeled amount and its availability to the body (Jabeen et al., 2006). The main objective of an oral tablet is to deliver the drug to the human body at certain and defined amount through the gastro-intestinal system for producing 
therapeutic effect (Islam et al., 2011). The formulation of the drug product can have a significant effect on the quality parameters such as weight variation, hardness, friability, disintegration time, dissolution profile etc. This also includes the physiochemical properties of the active ingredients and excipients as well as the procedures used in the manufacturing process (Ofori-Kwakye et al., 2010; Kalakuntla et al., 2010).

Moreover, quality control parameters also or physical properties of tablet are useful tools for maintaining consistency in batch-to-batch manufacturing and it should be performed for every drug product. All of these parameters are closely related to each other and have effect on drug absorption, bioavailability etc. (Awofisayo et al., 2010; Jain et al., 2012). The aim of the study was to evaluate the comparative quality control parameters between the tablets of two formulations because standard quality parameters are essential for better quality of medicine.

\section{MATERIALS AND METHODS}

\section{Study design}

Comparative in-vitro quality control parameters between the commercially available tablet brands of paracetamol and paracetamol/caffeine combination in Bangladesh were studied through the evaluation of weight variation, hardness, friability, disintegration time and dissolution profile. The study was done by performing various test procedures associated to assess the quality of tablets.

\section{Sample collection}

To perform the study both paracetamol and paracetamol/caffeine tablets of five different top level manufacturers were purchased from the drug store of Noakhali, Bangladesh. All the tablet brands of paracetamol were labeled to contain $500 \mathrm{mg}$ of paracetamol per tablet and the paracetamol/caffeine brands were labeled to contain $500 \mathrm{mg}$ of paracetamol and $65 \mathrm{mg}$ of caffeine per tablet. The labeled shelf life of all of the tablets was three years from the date of manufacturing and was taken for the evaluation before two years of the labeled expiry date.

\section{Sample identification}

After purchasing, tablets of all the brands were coded as A1, B1, C1, D1 and E1 for paracetamol tablets of five different manufacturers and A2, B2, C2, D2 and E2 for paracetamol/caffeine tablets of the same five manufacturers. Finally the coded samples were separated as a pair of paracetamol and paracetamol/caffeine of the same manufacturer and taken for evaluation.

\section{Procedure of evaluation}

Various analytical methods and tests are important for the development and manufacture of pharmaceutical formulations (Nijhu et al., 2011). For the evaluation, following quality control tests were performed for all the tablet brands of two formulations in the study.

\section{Weight variation test}

The variation of the weight of individual tablet is a valid indication of the corresponding variation in the drug content (Rawlian, 1977). Controlling tablet weights within a tight range will contribute to better tablet hardness and friability (Tousey, 2011).The acceptable limit for the deviation of weight for tablets having average weight of $250 \mathrm{mg}$ or more should not exceed 5\% (British Pharmacopoeia, 2005). Ten tablets were selected from each of the brand and weighed individually using electronic balance (Adventurer, OHAUS, USA, Model: AR2140). Their average weights were calculated. For all tablet brands following mathematical equation was used for weight variation (Kalakuntla et al., 2010):

$$
\begin{aligned}
& \text { Highest weight variation }=\frac{\text { Highest weight }- \text { Average weight }}{\text { Average weight }} \times 100 \\
& \text { Lowest weight variation }=\frac{\text { Lowest weight }- \text { Average weight }}{\text { Average weight }} \times 100
\end{aligned}
$$

\section{Hardness test}

Hardness indicates the capability of a tablet to withstand mechanical shocks during handling in manufacturing, packaging and shipping (Banker and Anderson, 2009). The acceptable range of hardness or crushing strength of tablet is 4 to $7 \mathrm{kgf}$ (kilogram of force) (Musa et al., 2011). During the study, hardness of all tablets was determined using Tablet Breaking Force Tester, USP-1217 (Electrolab: EH-01P). For both of the formulations, five tablets of each brand were taken and hardness of the tablets was determined. 


\section{Friability test}

Friability test is essential to evaluate the ability of a tablet to withstand abrasion in packing, handling and transporting. In the study, it was determined using Electrolab EF-2 Friabilator (USP). The value of friability was expressed in percentage (\%). Ten tablets for each brand were initially weighed and transferred into friabilator. The friabilator was operated at $25 \mathrm{rpm}$ for 4 minutes (up to 100 revolutions). The tablets were weighed again and the percent (\%) friability was then calculated by using following formula (Kalakuntla et al., 2010). Generally the considerable range of weight loss of conventional compressed tablet is less than 0.5 to $1 \%$ (Banker and Anderson, 2009).

$\%$ Friability $=\frac{\text { Weight before test }- \text { Weight after test }}{\text { Weight before test }} \times 100$

\section{Disintegration test}

Disintegration is the break down process of tablet into smaller particles and is the first step towards dissolution. The standard disintegration time for USP uncoated tablet must be as low as 5 minutes but majority of the tablets have a maximum disintegration time of 30 minutes (Banker and Anderson, 2009). The method specified in the USP/NF (1980) was used (Disintegration Tester- USP, Electrolab: ED- 2L). The volume of disintegration medium used was $100 \mathrm{ml}$ of $0.1 \mathrm{~N} \mathrm{HCl}$ and the temperature was maintained at $37 \pm 1^{\circ} \mathrm{C}$ throughout the experiment for each tablet of all the brands. Six tablets of each brand were selected and placed in each of the cylindrical tubes of the basket and the disc was used. The time taken to break each tablet into small particles and pass out through the mesh was recorded. Mean disintegration time was calculated for each of the brands (Gangwar et al., 2010).

\section{Dissolution test}

Generally dissolution test is carried out to determine drug release pattern during a specific period of time (Kishore et al., 2011). Dissolution test for each of the tablet brands was performed using Dissolution Tester - USP (Electrolab, TDT-08L Plus). $900 \mathrm{ml}$ of phosphate buffer, $\mathrm{pH} 7.4$ was used as dissolution medium (Kishore et al., 2011). The process was done at a speed of $50 \mathrm{rpm}$ by maintaining temperature at $37 \pm 1^{\circ} \mathrm{C}$ in each test. Samples were withdrawn as 5 $\mathrm{ml}$ at a regular time intervals of 10 minutes which was predetermined and same procedure was continued up to 30 minutes by replacing equal amount of fresh dissolution medium (phosphate buffer, $\mathrm{pH}$ 7.4). The filtered samples were suitably diluted and analyzed using UV Spectrophotometer (SHIMADZU UV Spectrophotometer: UV-1800$240 \mathrm{~V}$ ) at $257 \mathrm{~nm}$ for paracetamol. By measuring the absorbance, the percentage (\%) of drug release was calculated (Kishore et al., 2011; Kalakuntla et al., 2010).

\section{Data processing and analysis}

After the completion of all test procedures data for all the individual tablets were recorded and separated on a different sheets according to the manufacturer. Finally data were analyzed by using the above mentioned mathematical formula and MS-Excel®, 2007.

\section{RESULTS AND DISCUSSION}

During the study, at first the weight variation which is the key to controlling crushing strength and friability of tablet was assessed (Tousey, 2011). The unofficial test stated that all the samples of paracetamol coded A1, B1, C1, D1, E1 and samples of paracetamol/caffeine coded A2, B2, C2, D2, E2 have passed the weight variation uniformity test as specified in the British Pharmacopoeia (not exceed 5\% deviation) (British Pharmacopoeia, 2005). Weight variation uniformity between two groups of tablets was almost same though caffeine was added as adjuvant in one group.

Hardness is the second most important physical feature for assessing tablet (Tousey, 2011). In the study, it was found that A1, B1, C1 and E1 brands of paracetamol group passed the test of tablet crushing strength or hardness. These brands had acceptable crushing strength of between $4.31 \mathrm{kgf}$ to $6.98 \mathrm{kgf}$ except sample D1 which was the hardest of all the paracetamol tablet brands with a hardness of 9.17 $\mathrm{kgf}$, indicated that it was above the limit range of between 4 to $7 \mathrm{kgf}$ stated (Musa et al., 2011). On the other hand, the paracetamol/caffeine tablet brands had a crushing strength of between $5.99 \mathrm{kgf}$ to 11.55 kgf. Only A2 and B2 brands showed satisfactory crushing strength but the value of rest of the three brands C2, D2 and E2 were above the range. The study revealed that all the brands of paraceta$\mathrm{mol} /$ caffeine combination were harder than the brands of paracetamol. It might be the cause of 
Table 1: Evaluation of different quality control parameters of paracetamol and paracetamol/caffeine tablets.

\begin{tabular}{|c|c|c|c|c|}
\hline $\begin{array}{l}\text { Sample } \\
\text { (Tablet } \\
\text { brands) }\end{array}$ & $\begin{array}{c}\text { Weight } \\
\text { variation } \\
(\%) \\
\end{array}$ & $\begin{array}{c}\text { Hardness } \\
\text { (kgf) }\end{array}$ & $\begin{array}{c}\text { Friability } \\
(\%)\end{array}$ & $\begin{array}{l}\text { Disintegration } \\
\text { time (sec/min) }\end{array}$ \\
\hline $\mathrm{A} 1(\mathrm{P})$ & 1.21 & 5.15 & 0.34 & $36 \mathrm{sec}$ \\
\hline $\mathrm{A} 2(\mathrm{P} / \mathrm{C})$ & 0.98 & 6.91 & 0.09 & $6 \mathrm{~min} 33 \mathrm{sec}$ \\
\hline $\mathrm{B} 1(\mathrm{P})$ & 1.07 & 4.31 & 0.31 & $24 \mathrm{sec}$ \\
\hline $\mathrm{B} 2(\mathrm{P} / \mathrm{C})$ & 1.47 & 5.99 & 0.15 & $10 \mathrm{~min} 7 \mathrm{sec}$ \\
\hline $\mathrm{C} 1(\mathrm{P})$ & 2.03 & 6.98 & 0.27 & $2 \min 53 \mathrm{sec}$ \\
\hline $\mathrm{C} 2(\mathrm{P} / \mathrm{C})$ & 1.33 & 8.26 & 0.34 & $14 \mathrm{~min} 13 \mathrm{sec}$ \\
\hline D1 (P) & 2.14 & 9.17 & 0.21 & $39 \mathrm{sec}$ \\
\hline D2 $(\mathrm{P} / \mathrm{C})$ & 1.79 & 11.55 & 0.16 & $9 \min 5 \mathrm{sec}$ \\
\hline $\mathrm{E} 1(\mathrm{P})$ & 1.81 & 6.19 & 0.64 & $4 \mathrm{~min} 52 \mathrm{sec}$ \\
\hline E2 $(\mathrm{P} / \mathrm{C})$ & 2.09 & 11.23 & 0.11 & $17 \mathrm{~min} 43 \mathrm{sec}$ \\
\hline
\end{tabular}

$\mathrm{A} 1, \mathrm{~B} 1, \mathrm{C1}, \mathrm{D} 1, \mathrm{E} 1=$ Tablet brands of paracetamol alone A2, B2, C2, D2, E2= Tablet brands of paracetamol/caffeine combination $\mathrm{P}=$ Paracetamol $\mathrm{P} / \mathrm{C}=$ Paracetamol and caffeine combination $\mathrm{Kgf}=$ Kilogram of force; $\mathrm{sec}=$ Second $; \mathrm{min}=$ Minute

increasing tablet weight for combination formulation (Tousey, 2004).

In the friability test, all brands showed impressive friability values. The friability values for paracetamol tablet brands were ranged from 0.21 to $0.64 \%$ whereas the paracetamol/caffeine tablet brands showed 0.09 to $0.34 \%$ of friability. In all formulations the percent (\%) friability was less than $1 \%$ which ensures that all the tablets of each brand of both formulations were mechanically stable (Kalakuntla et al., 2010).

The disintegration time of all tablet brands of paracetamol A1, B1, C1, D1 and E1 was satisfactory as uncoated USP tablets have disintegration time standards as low as 5 minutes (Banker and Anderson, 2009). Whereas tablets of paracetamol/caffeine A2, B2, C2, D2 and E2 showed higher disintegration time though they also meet the maximum limit of 30 minutes (Banker and Anderson, 2009).The overall disintegration time for paracetamol tablet brands was in the ranged from 24 seconds to 4 minutes 52 seconds while paracetamol/caffeine tablet brands ranged from 6 minutes 33 seconds to 17 minutes 43 seconds. So the disintegration time for paraceta$\mathrm{mol} /$ caffeine tablet brands is much higher than the paracetamol tablet brands. The results obtained in the study showed that the hardness or breaking strength of the tablets directly relates with the disintegration time, i.e. more hardness of paraceta-
Table 2: Evaluation of dissolution profile of paracetamol and paracetamol/caffeine tablets.

\begin{tabular}{cccc}
\hline $\begin{array}{c}\text { Sample } \\
\text { (Tablet brands) }\end{array}$ & $\begin{array}{c}\text { (\%) Drug } \\
\text { release after } \\
\text { 10 } \mathbf{~ m i n}\end{array}$ & $\begin{array}{c}\text { (\%) Drug } \\
\text { release after } \\
\text { 20 } \mathbf{~ m i n}\end{array}$ & $\begin{array}{c}\text { (\%) Drug } \\
\text { release after } \\
\text { 30 } \text { min }\end{array}$ \\
\hline A1 $(\mathrm{P})$ & 49.78 & 88.08 & 103.57 \\
A2 $(\mathrm{P} / \mathrm{C})$ & 55.03 & 92.17 & 101.06 \\
$\mathrm{~B} 1(\mathrm{P})$ & 51.19 & 91.41 & 99.92 \\
$\mathrm{~B} 2(\mathrm{P} / \mathrm{C})$ & 57.11 & 94.13 & 105.02 \\
$\mathrm{C} 1(\mathrm{P})$ & 40.51 & 76.37 & 94.11 \\
$\mathrm{C} 2(\mathrm{P} / \mathrm{C})$ & 43.97 & 83.03 & 99.36 \\
$\mathrm{D} 1(\mathrm{P})$ & 38.92 & 69.42 & 96.5 \\
$\mathrm{D} 2(\mathrm{P} / \mathrm{C})$ & 46.39 & 76.92 & 98.15 \\
E1 $(\mathrm{P})$ & 43.19 & 79.71 & 95.41 \\
E2 $(\mathrm{P} / \mathrm{C})$ & 45.92 & 84.04 & 101.21 \\
\hline
\end{tabular}

A1, B1, C1, D1, E1= Tablet brands of paracetamol alone A2, B2, C2, D2, E2= Tablet brands of paracetamol/caffeine combination $\mathrm{P}=$ Paracetamol $\mathrm{P} / \mathrm{C}=$ Paracetamol and caffeine combination $\min =$ Minute

$\mathrm{mol} /$ caffeine tablets increased their disintegration time than the tablets of paracetamol (Ahmed et al., 1998). Results of weight variation, hardness, friability and disintegration tests are shown in Table 1.

Dissolution was another studied important quality control parameters directly related to the absorption and bioavailability of drug (Pabla et al., 2009). The study revealed that at different time intervals drug release rate was better in paracetamol/caffeine tablet brands comparing with the paracetamol alone. After 10 minutes, the release rate of tablet brands of paracetamol was 38.92 to $51.19 \%$ whereas release rate of paracetamol/caffeine tablets was 43.97 to $57.11 \%$ which showed that initial release rate of paracetamol/caffeine combination was more than paracetamol alone and this also continued after 20 minutes. Finally after 30 minutes, $99-100 \%$ drug release was observed in $\mathrm{A} 1$ and $\mathrm{B} 1$ for paracetamol brands and A2, B2, C2 and E2 for paraceta$\mathrm{mol} /$ caffeine brands. All other brands of both groups also showed more than $90 \%$ drug release after 30 minutes. The better dissolution profile of paracetamol/caffeine might be the impact of caffeine, as the solubility of paracetamol is accelerated by caffeine (Okore and Osuji, 2001). Outcome of the test has been shown in Table 2 and Figure 1. 


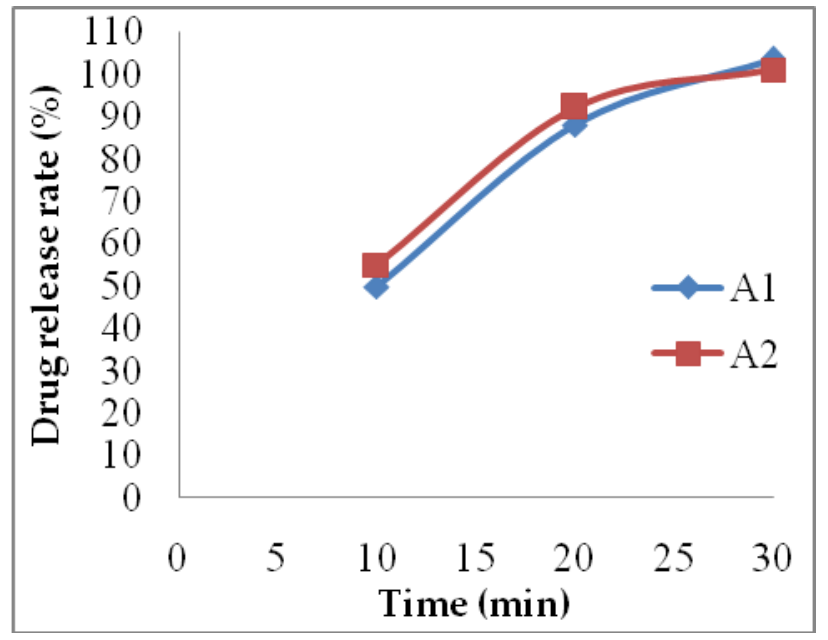

(a)

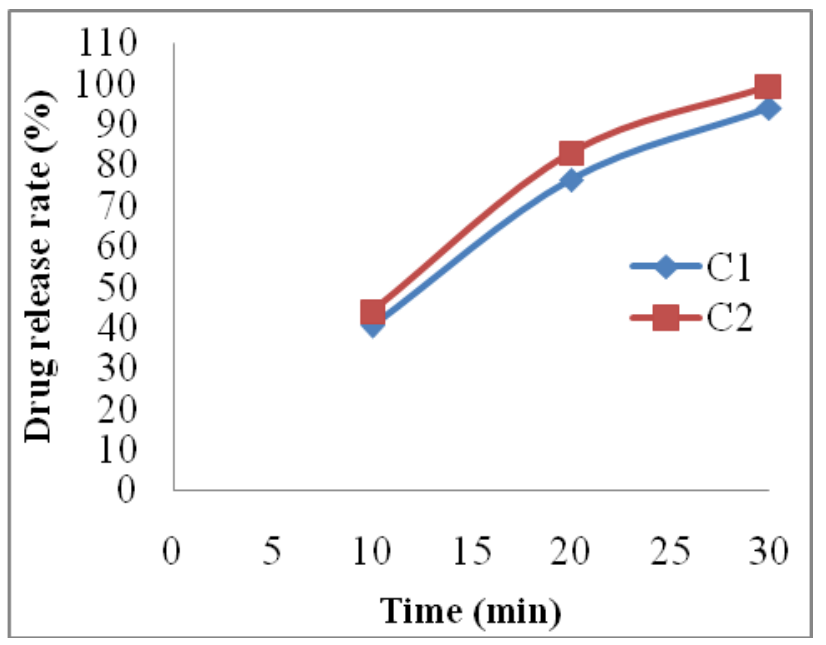

(c)

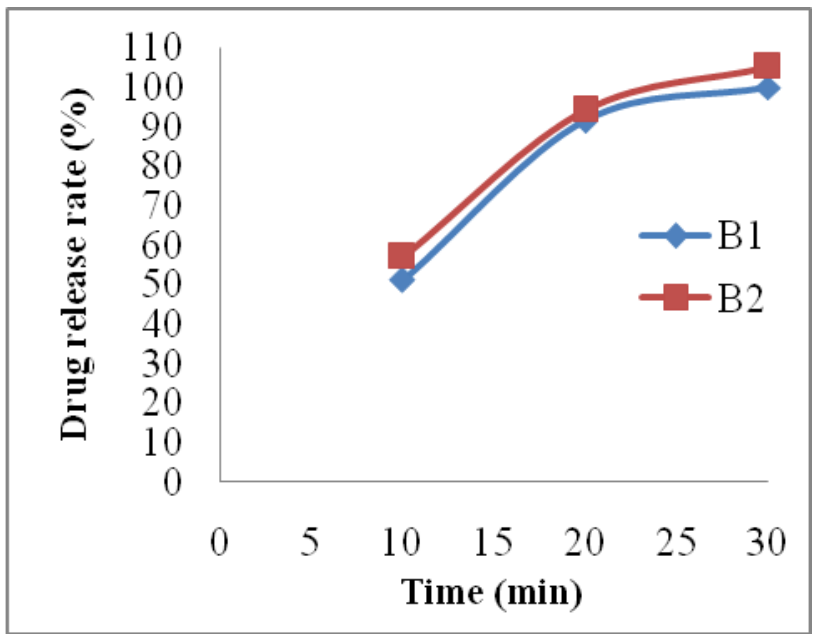

(b)

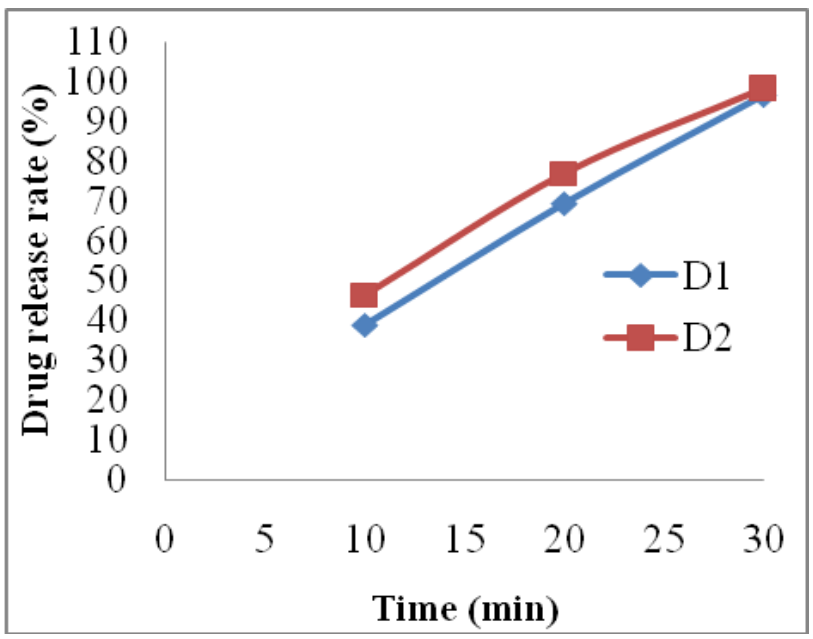

(d)

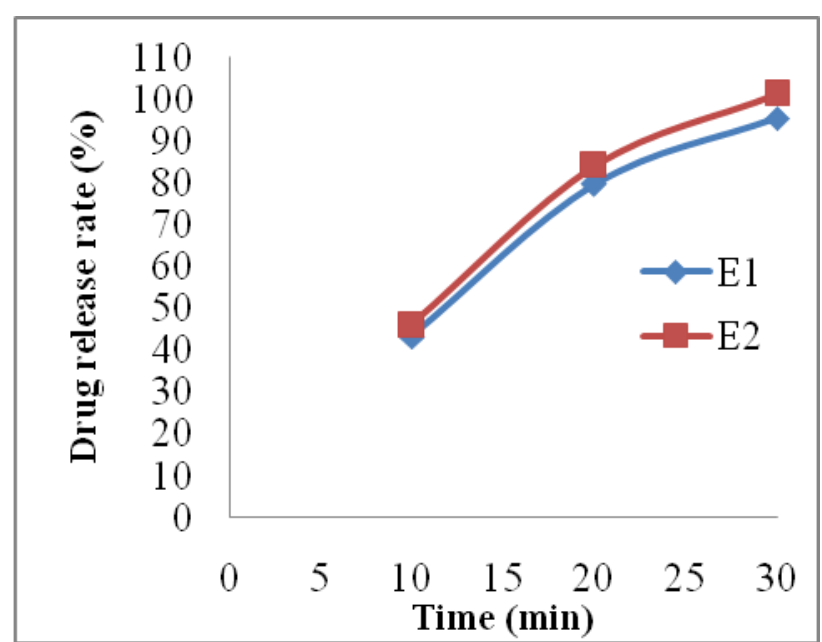

(e)

Figure 1: Dissolution profile of different brands a) A1 and A2, b) B1 and B2, c) C1 and C2, d) D1 and D2, e) E1 and E2.

A1, B1, C1, D1, E1= Tablet brands of paracetamol alone

A2, B2, C2, D2, E2= Tablet brands of paracetamol/caffeine combination 


\section{CONCLUSION}

Paracetamol is a well established and proven analgesic and antipyretic drug. The current pharma market of Bangladesh is flooded with various combination preparations. With other combination formulation, paracetamol/caffeine is also now widely used for the management of different pain in the country. Therapeutic response of any formulation depends on its quality parameters. From the study it was identified that weight variation and friability test of both paracetamol and paraceta$\mathrm{mol} /$ caffeine tablet brands complied the specification. Variation was obtained in hardness, disintegration time and dissolution profile during the test procedure. Paracetamol/caffeine tablets were found harder than tablets having only paracetamol and the combination brands also increased the time of disintegration. It should be strictly considered that an ideal tablet will have sufficient hardness to maintain its mechanical stability but not more. Because harder tablet can delay disintegration time or alter dissolution profile. On the other hand, paracetamol/caffeine tablet brands showed better disintegration profile than the single paracetamol brands. At every interval drug release rate was more in paracetamol/caffeine tablets than paracetamol alone. This might be resulted by the presence of caffeine in the formulation as it increased the solubility of paracetamol followed by dissolution profile. Finally, as quality control parameters are related to one another from initial step to pharmacological action of the drug, a high-quality tablet either single or in combination should meet all the standard quality parameter for getting its desired therapeutic response.

\section{ACKNOWLEDGEMENT}

The authors are thankful to Dr. Mohammad Salim Hossain, Chairman, Department of Pharmacy, Noakhali Science and Technology University for providing the laboratory facilities to perform the research work.

\section{REFERENCES}

Ahmed, A., Ali, S.A., Hassan, F., Ayub, S., Haque, N. (1998). Effect of disintegrants and hardness on the disintegration time of acetaminophen tablets. Pakistan Journal of Pharmaceutical Sciences, 11(1): 41-46. PMid:16414810
Awofisayo, S.O., Awofisayo, O.A., Eyen, N., Udoh, I.E. (2010). Comparative assessment of the quality control measurements of multisource ofloxacin tablets marketed in Nigeria. Dissolution technologies, 17(2): 20-25.

Banker, G.S. and Anderson, N.R. (2009). Tablets. In Lachman, L. and Lieberman, H.A, The theory and practice of industrial pharmacy (Special Indian ed., pp 229-345), CBS Publishers and Distributors Pvt. Ltd., India .

British Pharmacopoeia. (2005): Volume. 4, Appendix XII H A273, Table: 2.9.5-1.

Fiebich, B.L., Lieb, K., Hull, M., Aicher, B., Ryn, J.V., Pairet, M., Engelhardt, G. (2000). Effects of caffeine and paracetamol alone or in combination with acetylsalicylic acid on prostaglandin E2 synthesis in rat microglial cells. Neuropharmacology, 39(11): 2205-2213. DOI

Gangwar, S., Singh, S., Garg, G., Garg, V., Sharma, P.K. (2010). To compare the disintegrating property of papaya starch and sago starch in paracetamol tablets. Int J Pharmacy Pharm Sci, 2(Suppl 2): 148-151.

Gupta, A.k.(1994).Tablet. Introduction to pharmaceutics-I (3rd ed., pp 239-274), CBS Publishers and Distributors, India.

Islam, S.M.A., Islam, S., Shahriar, M., Dewan , I. (2011). Comparative in vitro dissolution study of aceclofenac marketed tablets in two different dissolution media by validated analytical method. Journal of Applied Pharmaceutical Science, 1(9): 87-92.

Islam, S.M.A., Shultana, S., Sayeed, M.S.B., Dewan, I. (2012) UV-Spectrophotometric and RP-HPLC methods for the simultaneous estimation of acetaminophen and caffeine: validation, comparison and application for marketed tablet analysis. Int J Pharm, 2(1): 39-45.

Jabeen, S., Ali, A., Hassan, F., Fatima, N. (2006). Studies on the effects of cyclodextrin polymer as a tableting aid on some selected analgesics. Pakistan Journal of Pharmacology, 23(1): 67-71.

Jain, N., Mandal, S., Banweer, J., Jain, S. (2012). Effect of superdisintegrants on formulation of taste masked fast disintegrating ciprofloxacin tablets. International Current Pharmaceutical Journal, 1(4): 62-67. DOI

Kalakuntla, R., Veerlapati, U., Chepuri, M., Raparla, R. (2010) Effect of various super disintegrants on hardness, disintegration and dissolution of drug from dosage form. J. Adv. Sci. Res, 1(1): 15-19.

Kishore, B.H., Venkareswararao, T., Sankar, K.R., Rao, B.S. (2011). Studies on dissolution rate of paracetamol tablets by using different polymers. Journal of Global Trends in Pharmaceutical Sciences, 2(1): 1-10.

Lipton, R.B., Stewart, W.F., Ryan, R.E. Jr., Saper, J., Silberstein, S. (1998). Efficacy and safety of acetaminophen, aspirin, and caffeine in alleviating migraine headache pain: three double-blind, randomized, placebo-controlled trials. Arch Neural, 55: 210-217. DOI PMid:9482363 
Liu, D.J., Kotler, M., Sharples, S. (2011). Pharmacokinetic and bioequivalence study evaluating a new paraceta$\mathrm{mol} / \mathrm{caffeine}$ formulation in healthy human volunteers. Journal of Bioequivalence \& Bioavailability, 3(11): 251-257.

Musa, H., Sule, Y.Z., Gwarzo, M.S. (2011). Assessment of physicochemical properties of metronidazole tablets marketed in Zaria, Nigeria. Int J Pharm Pharm Sci, 3(Suppl 3): $27-29$.

Nijhu, R.S., Akhter, D.T., Jhanker, Y.M. (2011). Development and validation of UV spectrophotometric method for quantitative estimation of nitroglycerin in pharmaceutical dosage form. International Current Pharmaceutical Journal, 1(1): 1-5. DOI

Ofori-Kwakye, K., Osei-Yeboah, F., Kipo, S.L. (2010). Formulation and quality evaluation of two conventional release tablet formulations. International Journal of Pharmaceutical Sciences Review and Research, 4(1): 94-99.

Okore, V.C., Osuji, A.C. (2001). A model study on caffeine paracetamol interactions. Acta Pharm, 51: 139-145.

Pabla, D., Akhlaghi, F., Zia, H. (2009). A comparative pHdissolution profile study of selected commercial levothyroxine products using inductively coupled plasma mass spectrometry. European Journal of Pharmaceutics and Biopharmaceutics, 72: 105-110. DOI PMid:18996189

Rawlins, E.A. (1977). Bentley's text book of pharmaceutics (8th ed., pp. 289-290), Bailliere Tindal publisher.
Renner, B., Clarke, G., Grattan, T., Beisel, A., Mueller, C., Werner, U., Kobal, G., Brune, K. (2007). Caffeine accelerates absorption and enhances the analgesic effect of acetaminophen. J Clin Pharmacol, 47(6): 715-726. DOI PMid:17442681

Sawynok, J., Yaksh, T.L. (1993). Caffeine as an analgesic adjuvant: a review of pharmacology and mechanisms of action. Pharmacol. Rev., 45(1): 43-85. PMid:8475169

Smith, R. (1998). Migraine relief with acetaminophen, aspirin, and caffeine: abstract and commentary. JAMA, 279: 1310. DOI

Tousey, M.D. (2004). Preventing and fixing weight and hardness defects: Strategies for production personnel. Tablet press operation. Available at: www.dipharma.com/Tousey_904TC.pdf [Accesses on: 08.03.2012]

Tousey, M.D. (2011). Tablet pro: A tablet making training resource for tablet making professionals. Techceuticals, 4(1):1-15. www.dipharma.com/TP_V4.pdf [Accesses on: 09.03.2012]

Ward, N., Whitney, C., Avery, D., Dunner, D. (1991). The analgesic effects of caffeine in headache. Pain, 44: 151-155. DOI 